\title{
FROM THE HEARTLAND TO THE HEAD OF THE DOG
}

\author{
Madam President . . . I wish to address another subject that is \\ crucial for the development of our country, a subject that concerns \\ the reaffirmation of our sovereignty especially with respect to \\ scientific and technological autonomy in more advanced areas of \\ innovation. In addition to the gains in basic research in a very new \\ area of technology, our country can benefit economically if we \\ develop the knowledge necessary to transform some rare minerals \\ that we have right here in our territory into the inputs for complex \\ and sophisticated products . . . I am referring to those which are \\ called "rare earths." \\ —Senator Luiz Henrique da Silveira (2013)
}

There are well-regulated rare earth producers established in Brazil's industrial heartland. So why are state, corporate, and indigenous actors campaigning to mine a remote and protected region of the Amazon?

In the wake of the 2010 crisis, public and private sector actors sought to "reglobalize" Brazil's rare earth industry to restore it to pre-World War II importance in global political economy (Lapido-Loureiro 2013). In particular, the stateowned geological research enterprise Mineral Resources Research Company (Companhia de Pesquisa dos Recursos Minerais: CPRM), jointly with the National Department of Mineral Production (Departamento Nacional de Produção Mineral: DNPM), received the largest federal budget in their history in order to reinvigorate their mandate to generate basic geological information about Brazil's thirteen million square kilometers of territory. This information was intended for the public and potential investors and meant to facilitate strategic resource extraction (Jones et al. 2011). In late 2011, the Ministry of Science, Technology and Innovation and the Ministry of Mines and Energy held Brazil's first seminar on rare earths in Rio de Janeiro, in which government geologists declared that Brazil possessed the largest known rare earth reserves of any country in the world (Lima 2012). As noted in chapters 2 and 4, each of the major finds examined in 
this work are purported to be the largest in the world. Although the content of these claims must be treated with skepticism, the work done by such claims in producing frontier space requires closer examination. In Brazil, these claims shape contemporary iterations of historical struggles between indigenous peoples, multiple state interests, and corporate and artisanal miners.

The objective of Brazil's first and subsequent rare earth seminars was to disseminate information on domestic rare earth reserves to diverse audiences. It was hoped that promoting the country's rare earth endowments would recruit investors as well as generate political will to organize a vertically integrated rare earth production chain in the country (Ferraz 2011). Here I examine diverse efforts over time to transform an explored site into a new rare earth capital. As with the complex territorial campaigns and immense shifts in global political economy that constituted the establishment of Bayan Obo as the rare earth capital of the world, the case of Brazil shows that much more than simple accidents of geology or invisible hands of the market drive the geography of the rare earth frontier. Since the 2010 crisis, multiple regulatory offensives have unfolded in order to make rare earth mining possible in Brazil's remote and protected regions. In 2012, the Senate established a temporary commission to elaborate a special regulatory code to facilitate domestic rare earth mining (Federal 2013). Framed in official discourse as strategically necessary to Brazil's technological innovation and increased international influence, rare earths are referred to as "bearers of the future" (portadores do futuro) ${ }^{1}$ (Diniz 2013), as crucial to national defense (Portales 2011), and as essential to the national sovereign development of Brazil (Henrique 2013).

Even before the liberalization of China's rare earth exports in January 2015, the Brazilian rare earth frontier displayed a spatial paradox that defied simple market logics. From 2011 to 2014, several rare earth frontiers emerged within a broader national developmentalist framework, two of which are presented in this book. The first concerned the aspirational challenge of procuring rare earth elements from existing, partially separated mine tailings at a state-of-the-art niobium production facility. This facility is situated on well-established infrastructure networks in the Brazilian heartland within a regional regulatory context favorable to extractive industry. The challenge, in this case, was to develop the technological capacity to remake the wastes generated by niobium beneficiation into a new rare earth frontier. With the major technological, regulatory, and infrastructural issues resolved, the remaining challenge for CBMM was to find downstream buyers willing to pay a premium for a sustainably produced, nonChinese source of rare earth oxides. Industry analysts explained the failure of the sustainable rare earths initiative strictly in terms of price competition: if CBMM could beat China's price, then they would dominate the global market. ${ }^{2}$ 
But there is more to the story. Simultaneous with CBMM's initiative, other mines opened and state geologists reexamined samples collected in the 1970s from a sacred hill in the northwestern borderlands. Called Morro dos Seis Lagos (Hill of Six Lakes), this site is located squarely in indigenous territory on the border with Colombia and Venezuela, in an ecological park on the eastern edge of the municipality of São Gabriel da Cachoeira (Simões 2011). This region, nicknamed Cabeça do Cachorro (Head of the Dog) because of the shape formed by national borders, is far from the only promising deposit in Brazil. It is perhaps the farthest-in political, ethical, and logistical terms - from the possibility of industrial development. Nevertheless, a small group of geological researchers, backed by state, military, and powerful investor interests, dusted off forty-year-old archives identifying a deposit that reportedly contains record concentrations of rare earths that could supply global demand for the next four hundred years (Lima 2011). The infrastructural constraints alone negate this proposition, as illustrated in figure 14 . This has not tempered the intense interests in mining rare earths in this region, however.

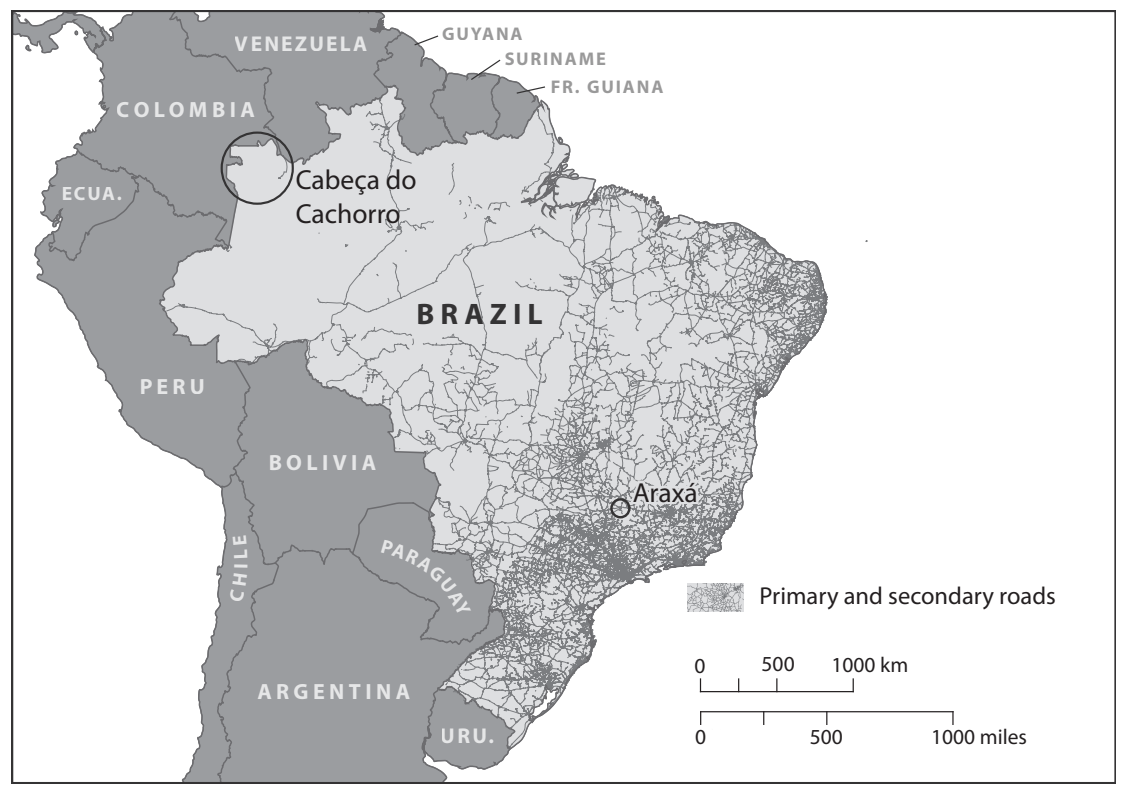

FIGURE 14. Location of Araxá and Cabeça do Cachorro. The map shows the relative density of Brazil's paved road networks on a national scale as well as the position of two of Brazil's rare earth frontiers. 
The basic paradox at work in the Brazilian geography of the rare earth frontier is this: even though reportedly abundant, technologically and environmentally superior high-purity rare earth oxides are already under production in Araxá-a site with well-developed physical and regulatory infrastructure-there is still a tremendous push to exploit rare earths and related elements in an inaccessible, legally protected, and politically inhospitable site located in the northwestern Brazilian Amazon.

Paradoxes cry out for some form of resolution (Proctor 1998). As with the cases of Afghanistan and Greenland, the debate concerning rare earth mining in Cabeça do Cachorro takes actual market concerns merely as a point of departure. In these new rare earth frontiers, longer-term struggles over territory, sovereignty, recognition, and geopolitics are (re)enacted through competing claims over these critical element endowments. In practice, these competing claims are exercised over the question of whose geological knowledge is recognized as legitimate, and which extractive practices are sanctioned by the state. Although the international community tends to see mining and rainforest conservation as diametrically opposed, among domestic stakeholders, including a diverse set of indigenous activists, the question of mining in Cabeça do Cachorro is not framed in terms of whether it should occur, ${ }^{3}$ but rather by whom and under what political economic conditions.

Because these struggles are not about whether state-sanctioned extraction takes place, but rather, by whom, certain elements characterizing the quest to tame the rare earth frontier in Baotou are recognizable here. Competing transnational actors surveyed the region with the ambition to consolidate territorial or geopolitical power by capturing the mineral and spiritual riches of this place, while struggles over who shall bear the mandate to mine these particular deposits are fused to dreams of sovereignty, desires for greater recognition, and the need to control the conditions of one's own development. That such an intense struggle is unfolding over the meaning and control over rare earth extraction in this region despite the economic and logistical infeasibility of such an enterprise indicates that there is much more at stake than the putative scarcity of rare earth elements, or even the quest to develop a national rare earth production chain. The struggle over the terms of mining in Cabeça do Cachorro is a clear instance in which historical continuities shape contemporary debates, changing the meaning of the latter through reenactments and reinterpretations of the former. In other words, rare earth elements are not the sole cause of contemporary struggles to determine the fate of the region. As in other cases, not even the presence of potentially minable deposits is sufficient to explain the conflict over the fate of the region's mineral endowments. Rather, it is because these particular deposits are strategically valued by powerful interests, which have interpreted rare earth 
mining in terms of longer-term territorial ambitions, that Cabeça do Cachorro emerges at all. It is neither history nor geology nor territorial politics alone, but a combination of the three.

Conflicting notions of sovereignty and security lay at the heart of the struggle over who shall mine rare earth elements in Cabeça do Cachorro. The stakes are amplified by ongoing geopolitical contests, three of which are the focus of this chapter: indigenous and artisanal struggles for greater political and economic recognition; multiple failed efforts on the part of extralocal powers to control transborder flows of people and commodities, and; border militarization in the context of the US global militarism. Because of these factors, this frontier, remote in distance and feasibility, has garnered greater political interest and international exposure than the more promising frontier manifest in the technological breakthroughs in Araxá. These asymmetrical interests in mining are better explained by the way in which rare earths shape longer-term struggles in Cabeça do Cachorro, rather than by any actual scarcity of rare earths themselves. This is another case that illustrates how the rare earth mining is a means to broader territorial ends.

Although the historical continuities are important, there is something fundamentally new about the debates concerning resource extraction in Cabeça do Cachorro that is scarcely visible in Anglophone discourses. Namely, the manner in which indigenous mining proponents are engaging in struggles over the fate of various legal conventions currently prohibiting mining on their constitutionally recognized lands. Contrary to prevailing representations in academic and advocacy work on the relationship between Amazonian peoples and mining, there neither is a unified "Indigenous" perspective nor is the debate drawn along the lines of indigenous opposition to mining as colonial invasion.

To some extent, the prevailing notions are understandable. The weight of centuries of historical memory, etched deeply with the racialized hierarchies of colonial brutality, overwhelm more nuanced perspectives on indigenous peoples and mining in this place referred to as the "end of the world."4 But the struggles around mining in Cabeça do Cachorro demand a more complex view of indigenous politics in the Brazilian Amazon.

In particular, the diversity of positions on extractivism and the alliances among actors generally portrayed as opponents are crucial to understanding the stakes of rare earth mining in the region. The sometimes deadly conflicts over who is entitled to mine, and in what manner, are centered on the meaning and circulation of geological knowledge unfolding over multiple temporal scales. All aspects require due consideration to make sense of this point on the global rare earth frontier. This chapter uses the production of geological knowledge and the struggle for control over the definition of the rare earth frontier as the lenses through which to bring these complex dynamics into focus. 


\section{Competing Sovereignties: Indigeneity, NGOs, and the Military}

Cabeça do Cachorro has been positioned as the frontier of many ambitious powers since the 1600s. Over the centuries, extractive interests have colluded with imperial and state powers in order to discipline, rationalize, and exploit the subsoils of this place, all with varying degrees of failure. Cabeça do Cachorro is situated on the upper reaches of the Rio Negro River in a historically contested border region between Brazil, Colombia, and Venezuela. Slavers, missionaries, rubber companies, and treasure hunters large and small have attempted to wrest the region's wealth from local hands. Violence periodically flares between indigenous people, outlaw geologists, police forces, and traffickers of various sorts. Seventyeight percent of the population belongs to one of the twenty-six indigenous groups ${ }^{5}$ possessing pre-Colombian histories in the area extending back at least three thousand years (Neves 1998). Their collective land rights were legally recognized by the federal government in 1996 with a demarcation of five continuous protection areas totaling approximately 10.6 million hectares, as shown in figure 15. No one, not even the military, is allowed to enter indigenous lands without permission. Today, the region is governed by a working alliance between indigenous federations, the Brazilian military, and a rotating cast of civil servants.

The region can only be accessed by air or river transport. Although indigenous and environmentalist victories in the 1980s and 1990s deterred many large-scale extractive interests, in early 2011 the Brazilian government announced that it would encourage exploration for rare earth deposits in the Amazon. President Dilma Rousseff personally invited the firm Companhia Vale do Rio Doce to identify new mining sites (Gozzi 2011), which inspired other enterprising geologists to follow suit. Since then a troubled alliance among military planners, state geologists, small-scale miners, indigenous activists, and federal government officials has coalesced around a struggle to rewrite the hard-won state and federal laws that have categorically prohibited mining in Cabeça do Cachorro for the past three decades.

At present, an executive order, a constitutional amendment, and several acts of congress would be necessary to repeal the constitutional measures forbidding mineral exploration and extraction in this sensitive and protected region. This is a separate matter from the conservation measures discouraging regional infrastructure construction. Long-standing contests over national sovereignty, indigenous citizenship rights, and basic livelihood security in Cabeça do Cachorro lie at the core of the impetus to exploit rare earth elements in such a challenging context. As in other sites examined in this book, material concerns over rare earth supply security are secondary to the imagined geopolitical spoils to be won by controlling their extraction in these remote frontiers. 


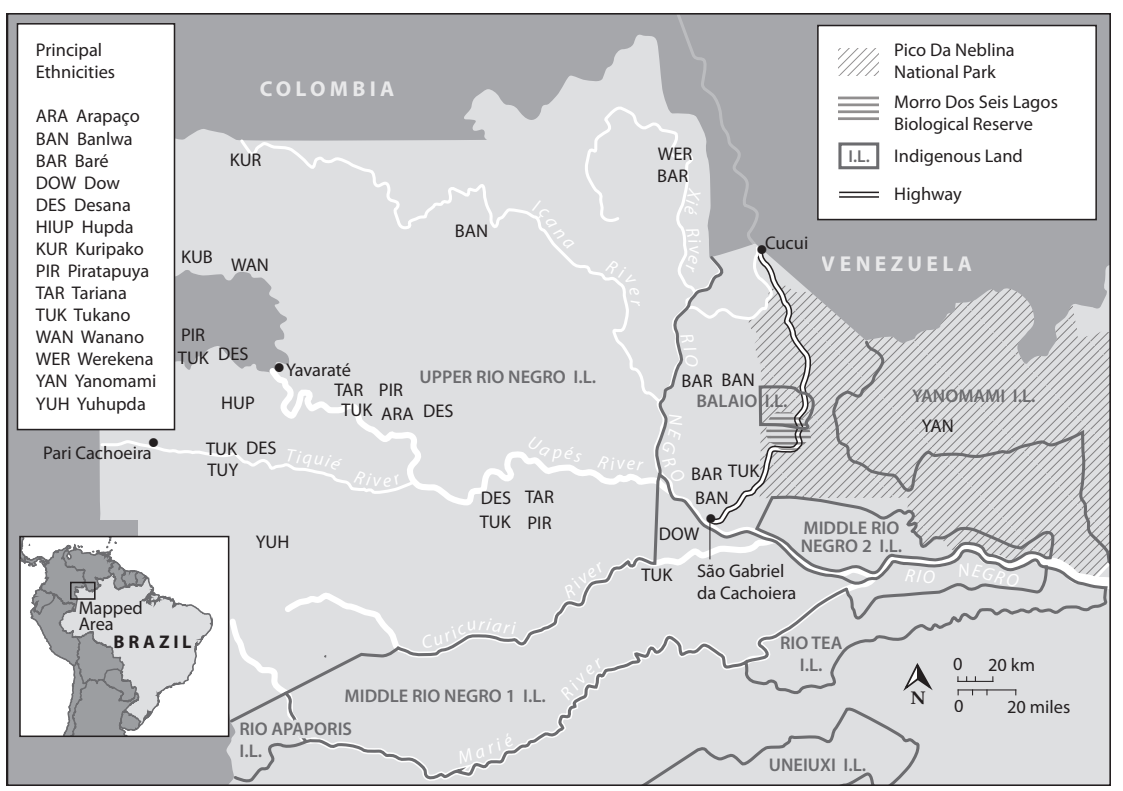

FIGURE 15. Detailed map of land demarcation and principle ethnicities in Cabeça do Cachorro.

Sources: Ricardo and Ricardo (2006). Image by Molly Roy.

This has generated some strange and perilous alliances. At a conference organized by the commanding general of the Amazon Military Command (Comando Militar da Amazônia; CMA), senior military officers, state planning officials, geologists, artisanal miners (garimpeiros) ${ }^{6}$ and Indigenous mining proponents assembled in Manaus on April 26, 2014 to discuss the subject of rare earths and strategic geopolitics. In an open comment session following a series of lectures on these subjects, ${ }^{7}$ the entanglement between rare earths and competing visions for the territory was laid bare in an exchange between veteran geologists, an Indigenous garimpeiro, and the commanding general of CMA. To start, a senior geologist who had participated in the preliminary geological explorations of Morro dos Seis Lagos during the military dictatorship said the following:

I am here weeping before you because it has been thirty-nine years since I graduated with a degree in geology ... forty years ago, we went up the Rio Negro doing our research, finding the resources that would develop our nation and FUNAI ${ }^{8}$ chased behind and said "No, this is Indigenous land." But I have confidence that you, here, who defend our sovereignty [gestures toward audience primarily composed of three and four-star 
generals], are going to wipe the tears from our eyes that come from seeing so much poverty amidst the riches that we have conditions to develop.

This inspired a lead geologist with the local DNPM to say the following:

After São Gabriel became a biological reserve and Indigenous territory, we had to cease all mineral research activities. But what we have there, I tell you - the greatest niobium deposit in the world, with rare earth concentrations previously unheard of-is a national patrimony. It would bring tremendous returns to all of us Brazilians.

The demarcation of Indigenous lands and conservation areas is financed by European and North American and Japanese banks. The Brazilian government is coordinating the process, but all of the money comes from international environmental entities and banks that want to lock up Brazil's resources, because they know that they are not going to fare well if they have to enter into competition with a developed Brazil! We have let this go on for too long! Too long! [Applause]

Enough with all of this concern for the Indians! Enough with creating conservation areas! The Indians are not interested in conservation areas; they are interested in mining and development! [Addresses Indigenous activists in the audience] International NGOs [nongovernmental organizations] are lying to you! They don't want you to know that beneath you are tremendous riches! They want you to continue being poor, to continue being simple! The international NGOs are never going to let you grow! They want to keep you stupid, illiterate!

They are making Indigenous areas and putting you there like you are some kind of animal and they aren't giving you a single legitimate economic activity. It is a degradation of your very lives! You want to work and develop, but it's prohibited! You can't mine, you can't develop tourism, you can't do anything. Because everything that would be good for you is prohibited. [Applause].

In response to this, an Indigenous garimpeiro took the floor and introduced himself as a member of the Tukano people, a military veteran, and the organizer of a small mining cooperative:

Folks, when I hear you talking about how the world is not letting us develop, it is very hurtful. We are as Brazilian as you. Our condition is not the fault of the world.

We are the most mineral rich country in the world, and we don't have our own affairs organized. We are dependent on China! This is pathetic, folks. Today: no, it should have been done yesterday; the law that permits 
us to mine on Indigenous lands must be regularized. But it is not the world, it is we Brazilians who make the laws. These laws need to be changed, and we are the ones to change them.

People go out claiming to represent the Indians. They say Indians don't want small-scale mining [garimpagem]. They say Indians are puppets of politicians. Politicians say Indians are puppets of NGOs. And when this country doesn't have progress people blame the Indian. They say: the Indian is interfering with our development. The Indian is not interfering with anything. The Indian wants progress! The Indian wants to help secure the frontier!

... I have formed a mining cooperative because I have hope in Brazil. We hope to obtain a concession to have a small mining operation in my region so that we Indigenous people, ourselves, can bring minerals to augment the nation's economy, which we need so badly. So I hope you will understand me when I say that the NGOs are hindering us in our efforts to move forward. Expel the NGOs from our lands! We want progress.

This speech garnered a standing ovation. Next came the general's closing remarks, in which he projected a map showing the largest deposits of rare earths and other high value mineral commodities in the Amazonian region. He then super-imposed a map indicating Indigenous lands and conservation areas, which covered many of the largest deposits (see figures 16A and 16B). "It would seem that Indians really like minerals," he said, which provoked laughter. He continued:

You know, I made this same joke at a presentation in São Paulo and somebody denounced me to the Public Ministry for disrespecting Indians. I hope you will forgive me; I made such an ironic statement because the Indians, you, my Indigenous brothers, are tools. You are tools being used in this process that [the DNPM geologist] characterized very well. Mining is the basis of sovereignty, yet we are preoccupied with human rights questions about things that happened forty years ago, and in the meantime, we have completely incapacitated ourselves from enacting concrete solutions to our problems.

No one had mentioned human rights or the military dictatorship during the conference, so the general's unprovoked reference is a telling indication of the ideological continuities underlying military concerns toward the Amazon. ${ }^{9}$ Furthermore, the exchange indicates how perilous the Indigenous mining position becomes in the face of competing territorial agendas. The general's response to the indigenous activist shows that despite a declaration of loyalty, a claim to military 
fraternity, and a condemnation of NGOs, the Indigenous are seen as obstacles to corporate or militarized extractivism. Indigenous control over mining in Indigenous lands does not qualify as a "concrete solution" and does not satisfy the military's vision of sovereign control over the Amazon. Only the domination of Amazonian landscapes and lives through large-scale industrialization will suffice. So long as Indigenous counterparts propose anything other than acquiescence, they are seen as tools of international NGOs lacking the capacity to control their own affairs.

There is a way in which international environmental and Indigenous rights campaigns, on the one hand, and indigeneity scholarship, on the other, align with the general's dismissal of Indigenous claims to mine within their own territory, on their own terms, for their own economic gain. The relationship between people and nature in indigeneity discourse often frames Indigenous agency in terms of a "more balanced" relation to nature that has not entirely let go of the "noble savage" tropes (Redford and Stearman 1993). As a result, there is virtually no conceptual space for the figure of the Indigenous miner. With remarkably few exceptions (Graulau 2001; Lahiri-Dutt 2011), mining does not even enter into

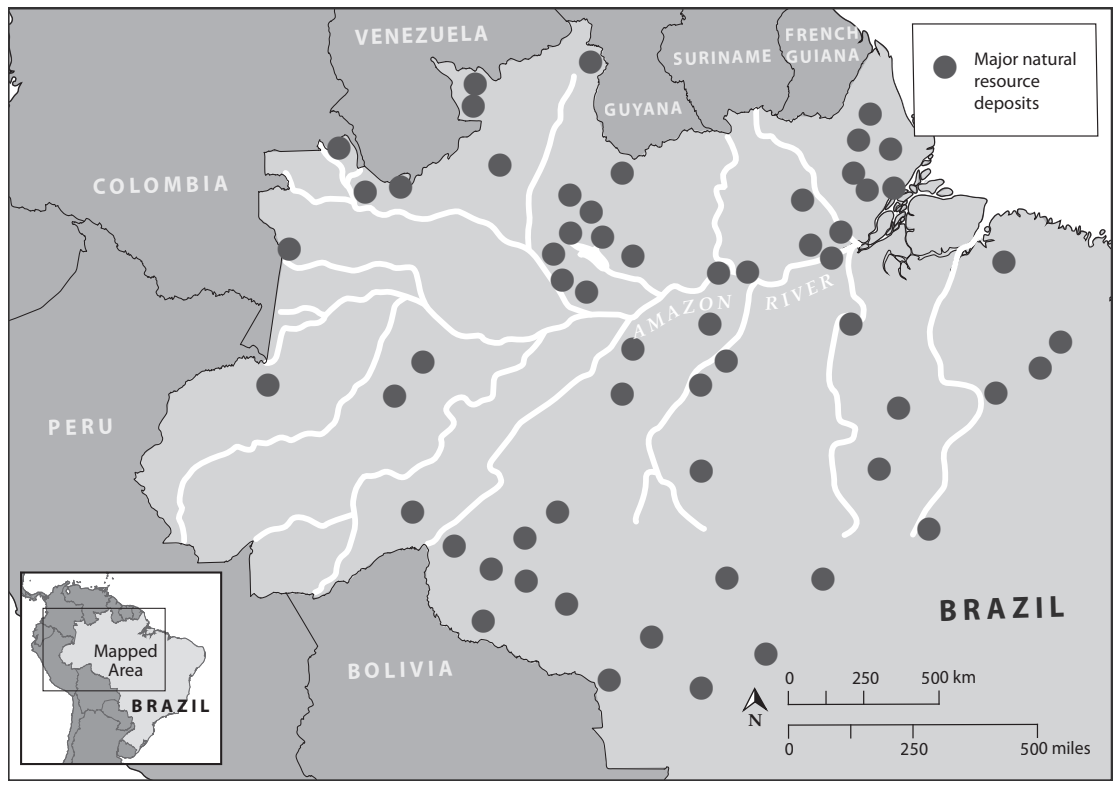

FIGURE 16A. Adaptation from a widely circulated slide presentation used by the General of the Amazon Military Command. The first slide indicates several areas of major known mineral deposits in the Brazilian Amazon. 


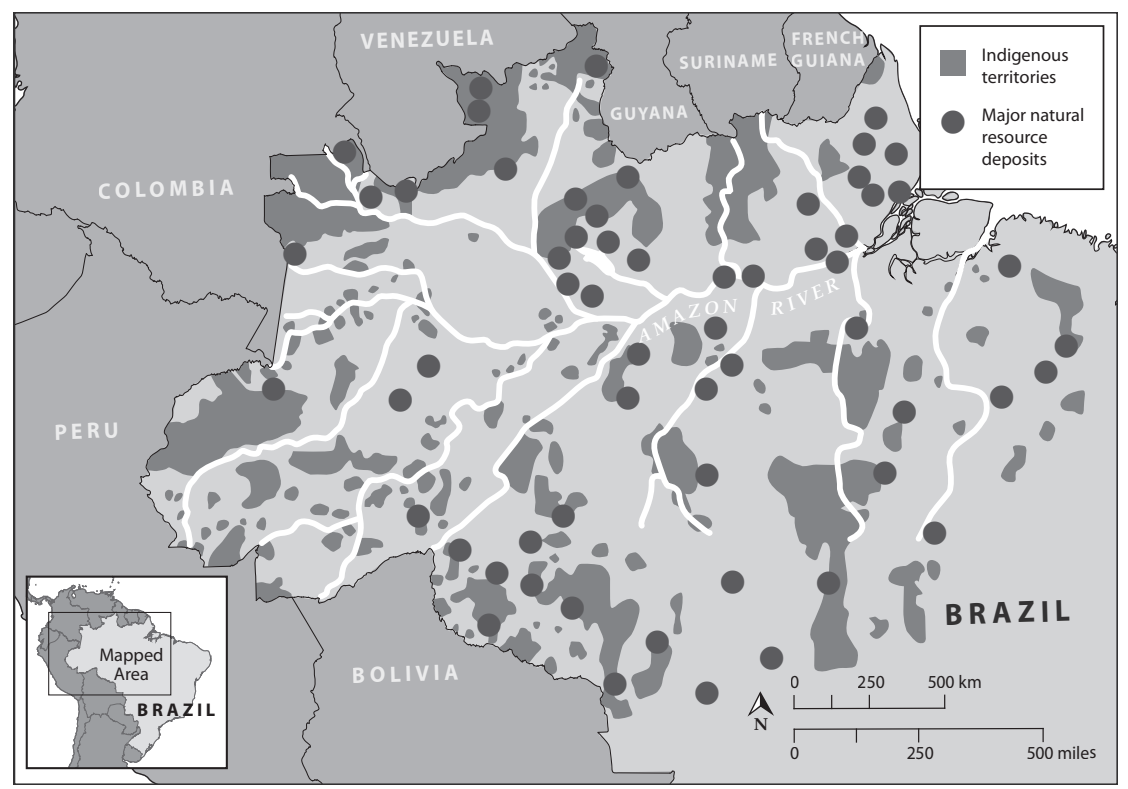

FIGURE 16B. Adaptation of the second slide showing mineral reserves overlaid with Indigenous lands and conservation reserves.

Source: Image by Molly Roy.

consideration as a legitimate economic activity for Indigenous peoples: not in the international conservation movements, not in the majority of literature on indigeneity, and not in the perspective of the Brazilian military. ${ }^{10}$

Exiled from transnational advocacy networks, but not recognized as being wholly Brazilian, the exchange between the Indigenous miner and the general indicates the limited agency attributed to contemporary indigeneity. Furthermore, whether and how Indigenous people in São Gabriel da Cachoeira actually identify with notions of indigeneity circulating globally and in domestic Brazilian discourse is a question seldom asked of Indigenous activists in the region. In international conservation discourse, the intense duality of mining as destruction wrought by outsiders versus the image of Indigenous people as environmental stewards ${ }^{11}$ does not account for the difference between corporate and small-scale mining activities. Indigenous mining proponents are dismissed as "coopted Indians" (Índios cooptados) and find themselves forced into an impossible space of silence on the matter of basic citizenship and usufruct rights. But silence would amount to acquiescence to the frontier-taming visions of distant powers, allowing no space for indigenous agency. So silence is not an option. 
As written, the law differentiates between horizontal and vertical land use rights. Indigenous people are legally entitled to the use of everything above forty centimeters depth (to allow for cultivation) contained within their federally recognized lands. Everything beneath this depth is reserved as property of the federal government and part of the national patrimony (Patrimonio da União). The current status quo relies on an explicitly spatial compromise: Indigenous people are entitled to horizontal land use to sustain themselves, while the state asserts exclusive control over vertical territory. Legally, nothing can be extracted from below forty centimeters without paying royalties to the federal government. But the permitting process is prohibitively expensive and garimpeiros face the risk of being violently displaced by large-scale mining companies should they register their holdings. ${ }^{12}$ Further complicating the issue is the geological incidence of rare earth elements in the region. Many rare earth deposits on Indigenous lands in Cabeça do Cachorro are found at, or very close to, the surface of riverbanks and streambeds. Since "mining" these types of deposits requires little to no digging, it is actually ambiguous as to whether this constitutes an exploitation of horizontal or vertical territory.

The state denial of vertical land rights to Indigenous people and the particular geological incidence of rare earth elements on Indigenous lands in Cabeça do Cachorro has generated some confusion, as illustrated by the ordeal suffered by veteran local leader in the Indigenous rights movement Mr. Santos. In early 2011, Mr. Santos noticed bluish green stones and clays at the mouth of a riverside cave within his lands. He sent a sample to a geologist friend in Manaus for analysis, who confirmed an unusually high concentration of rare earths. This geologist subsequently informed a buyer who quoted a price that was noticeably higher than what Mr. Santos recalled his other acquaintances ever receiving for their mineral shipments. This was in 2011, when global rare earth prices were still quite high, although Mr. Santos was unaware of the reasons at the time. He arranged to fill a four-meter long boat with raw material and transport it to Manaus to sell. ${ }^{13} \mathrm{He}$, his friends, and his family joined in the effort:

There was nothing clandestine about this. My friends and family gathered and loaded rock in the plain light of day, and I took the boat down river, stopping in the city [of São Gabriel] for lunch. I secured the boat on the beach in front of the federal police post and when we returned from lunch the federal police asked me: "Mister, is this your boat?" I said yes. They asked me: "Where is your fiscal note for these materials?" And I said: "Fiscal Note? What fiscal note? This is from my land." The Police said: "You robbed these resources from Indigenous lands?" And I said, "Robbed, what's this? I am from that land, I found 
these rocks, and my relatives helped me gather them." The police informed me that removing minerals from Indigenous lands was a crime. They seized my boat, arrested me, and sent me to jail in Manaus, where I was charged with illegal mining and environmental crimes. I was sentenced to six months in jail and assessed a fine for picking up stones on my land. Now I, a fighter [for Indigenous rights], invested in the reform of the legal system of our country, and the father of two young daughters, must return to Manaus several times each year to report to the Justice. I conducted my business in the plain light of day, and now I am a criminal. ${ }^{14}$

Mr. Santos and his family had planned to use the money from mineral sales to purchase a computer for his daughters and to take care of medical expenses needed by some community elders. In a region where social relations were largely nonmonetized, certain essential goods and services nevertheless require cash. Exchanging a boatload of rocks for a good price seemed to be an entirely legitimate means to acquire currency. Mr. Santos was not the first to experience this. A newspaper report from 2001 reported a similar affair, in which a member of the garimpeiro cooperative Cooperíndio was intercepted by the federal police in Manaus with a boatload of amethyst and tantalite (Brasil 2001). The cooperative has since politicized its activities, deploying white Brazilian garimpeiros to engage with allies in the DNPM and pro-mining interests in the CMA in an effort to shape national mining policy to protect smallholder interests. ${ }^{15}$

At stake in this debate over who mines in what way is the question of who has the right to define and conquer Brazil's geological frontiers. This is, at its core, a question of citizenship, which at present only extends to large-scale corporate actors and from which Indigenous people and garimpeiros have been excluded because of the costly barriers to legal mining. Put another way, Indigenous people do not have the means to conquer their own geological frontiers in ways that are recognized by the state. The sense that an unknown entity could take the earth from beneath one's feet is a chronic source of insecurity among Indigenous people, who cite mining entitlements as a matter of fuller citizenship rights within Brazil. Currently, only wealthy prospectors and established firms can afford to comply with the law as it is written. This suggests that the law was written for a specific notion of citizenry that excludes both garimpeiros and the Indigenous.

The legal codification of extractive entitlements extends state-backed corporate power to this enduring frontier and porous border region. This preference for large-scale corporate mining over small-scale indigenous extractivism illuminates the states' attempts to selectively (dis)empower certain agents to execute its territorial agenda. This is a striking example of how history shapes the present 
by reinscribing the opposition between Luso-Brazilian colonizers and Indigenous peoples. In this case, the struggle unfolds over who is entitled to exploit the nation's geological patrimony in order to control this point on the global rare earth frontier. This racial codification of legal and illegal mining erases any possible constructive alliance between the figures of the indigenous miner and the Luso-Brazilian garimpeiro.

Indigenous mining activists as well as white garimpeiros argue against these obtuse identity politics informing current state policy with logical and legal propositions. Those interviewed have identified two primary issues behind the state's rationale for criminalizing their activities. First, the prohibitively expensive permitting process means that garimpeiros are not conducting mining in a way that allows the state to collect royalties. Second, the clandestine nature of their activities means that they cannot organize investment or other programs to implement environmentally superior technologies. They expressed a firm desire to formalize their operations in order to reduce the social and environmental danger that plagues their currently lawless trade. In other words, they understand the problems and propose solutions: legalization, regularization, and state prioritization of small-scale mining activity as an antipoverty measure. These efforts to engage in policy reform complicate the position of the garimpeiro in Amazonian politics, which is perhaps why they are only selectively acknowledged in broader Anglophone and Lusophone discourses on the region.

In general, garimpeiros are cast as villains in Amazonian conservation and Indigenous rights politics. They are condemned for destroying the environment, invading Indigenous lands, and for wreaking murderous havoc wherever they go (D’incão 1994; Guimarães 2010; Hoefle 2013, MacMillan 1995; Slater 1994). There are important truths to these characterizations, but they are too simple. It does not allow for the possibility of Indigenous and garimpeiro cooperation. It racially codifies mining activity by presuming that only whites conduct mining on Indigenous lands and that Indigenous people are opposed to mining because of some innate quality of their indigeneity. Such a characterization forecloses the possibility that Indigenous people might also be garimpeiros, engaged in mining of their own volition, as part of their own livelihood practice, on their own lands.

Because Indigenous people are only permitted to use minerals found within the first forty centimeters of subsoils on their land for traditional and spiritual purposes, Indigenous mining proponents argue that the law is designed to keep them in a state of nature. By confining their usufruct rights to the realm of ceremony, the protections do not allow them to advance or live as modern citizens of Brazil. The Federation of Indigenous Organizations of the Rio Negro, (Federação dos Organizações Indigenas do Rio Negro; FOIRN) in particular has been at the forefront of condemning the current legal regime as primitivist, 
classist, and racist insofar as it only makes it possible for those who can afford the up-front permitting costs to comply with the law, while criminalizing customary activity regardless of how necessary small-scale mining might be for local livelihood security in the context of a globally integrated Brazil. ${ }^{16}$ But because proposed revisions to the federal mining code would repeal the moratorium on indigenous lands while also outlawing mining for all but major corporations (Coêlho 2013), Indigenous activists and politicized white garimpeiros are engaged together in a multipronged fight against corporate interests in the Brazilian Senate. Their goals are to legalize and grant statutory protection to small-scale mining operations on Indigenous territory, to prioritize indigenous governance and prohibit large-scale corporate mining by foreign firms. Only then, they argue, will they rise from their status as criminals at worst and second-class citizens at best.

The struggle represents a claim to citizenship and belonging that is outside the categories typically ascribed to both Indigenous and extractive interests. The claim for greater Indigenous autonomy over Indigenous lands is actually a claim to belonging to the Brazilian nation. André Baniwa, elected deputy mayor of São Gabriel da Cachoeira expresses it thusly: "Being Indian means knowing one's own culture, traditions, and maintaining one's identity without failing to know the Brazilian state [and] the culture and tradition of the nation" (Baniwa 2009 quoted in Guzmán 2013, 50). The struggle over the mining code, as it unfolds between Indigenous leaders and the state, is characterized by a demand on the part of Indigenous garimpeiros to participate in national development through smallscale mining on one's own lands and on one's own terms. ${ }^{17}$ Indigenous mining proponents also argue their case in geopolitical terms, maintaining that greater control over their local resources would empower them to exert greater control over the Brazilian border while also capturing a greater share of the global rare earth frontier for the benefit of the country.

One Tukano member, Mr. Barreto, has had a small-scale mining project that he began in 2013 to promote as a model for a sustainable development policy: "The activity would seek profits, not from the point of view of the capitalist world but from the measure of sustainability using traditional techniques and Indigenous conceptions and taking into account the relationship with nature. We do not want large companies and large corporations doing the work"18 (Barretto quoted in Farias 2013a).

However, both environmentalists and their political opponents in the Senate have misapprehended this sentiment. On the one hand, certain politicians pointed to Indigenous desires to mine their own lands in order to justify the liberalization of mining on Indigenous lands writ large, in exactly the terms Indigenous activists oppose. On the other hand, the international environmental conservation community has been vehemently opposed to changing the mining code on 
Indigenous lands under any terms whatsoever. In their global campaigns to pressure the Brazilian Senate to vote against procorporate, anti-indigenous mining measures, international NGOs have privileged a simplified narrative of Indigenous interests. The hope is that this will serve to keep the federal government and allied military and corporate interests out of indigenous lands. But the stakes of this form of representation are high. Military interests see allied indigenous and international NGO efforts as an affront to national sovereignty and security, and have responded by putting forth Ministerial Order 7957. This would allow state ministries to request the use of military force against Indigenous people who oppose large-scale development projects. This is an especially illustrative example of the way in which law reflects and reproduces power relations in society, rather than objectively arbitrating among them.

In a 2014 tour sponsored by Survival International, the renown Yanomami shaman Davi Kopenawa spoke to diverse audiences around the world to generate international opposition to mining on Indigenous lands (Bayer 2014). ${ }^{19}$ This international campaign against Amazonian mining furthered the racial codification of extractivism insofar as the problem was framed in terms of white miners invading pristine Indigenous lands populated by people who had no interest in mineral exploitation. While it is true that capitalist mining is understood as a degradation of the land and a violation of the Indigenous cosmos (Kopenawa and Albert 2013), small-scale mining is not understood in these same terms (Graulau 2003; Hinton, Viega, and Beinhoff 2003). ${ }^{20}$ Unfortunately, the international campaign traffics in the primitivist vision of Indigenous peoples against whom activists and inhabitants in Cabeça do Cachorro have been fighting. There is, of course, fierce debate within indigenous communities regarding the practice and proliferation of mining. The point is that there exists a plurality of perspectives.

The current success of the international campaigns comes at the expense of more nuanced proposals intended to give Indigenous people greater control over their lands, such as those advanced by FOIRN and local activists. This has generated intense resentment against international NGOs among Indigenous interviewees and mining proponents, but the antipathy goes both ways. Environmental activists dismiss Indigenous pro-mining arguments as not representative of the real concerns of the community, suggesting that Indigenous garimpeiros have been tainted by greed or brainwashed by military propaganda. This erases the fact that many of the mining proponents interviewed have been involved in the Indigenous struggles since the bloody days of the 1970s and 1980s. ${ }^{21}$ The purpose of these struggles, from the outset, was to establish Indigenous control over Indigenous lands.

In the view that emerged from the concentrated gathering of diverse mining interests at CMA headquarters in Manaus, conservation and Indigenous protec- 
tions were cast as an injury to Brazilian sovereignty insofar as they constrict the power of the state to conquer the Amazonian frontier in the name of rare earths. The relationship between centralized Lusophone power and the people living on the Amazonian frontier has changed little over the past few centuries: Indigenous entitlements to the land are a hindrance that would be best dealt with by the imposition of large-scale mining activities and the obliteration of existing local territorial orders. Not even an Indigenous investment in the extractive effort, expressed directly to military officials and state geologists in the name of national development and frontier security, could unseat this entrenched frontier narrative.

International NGOs position Indigenous mining proponents as coopted by corporate and military interests, but federal policymakers and military officials dismiss Indigenous mining proponents of the sort referenced above as indistinguishable from the traitors who have aligned themselves with international NGOs against the Brazilian state. Under the latter framing, both NGOS and Indigenous mining proponents demanding special protections against outside interests are accused of stalling national progress by "locking up" the strategic minerals of the Amazon in conservation reserves and Indigenous lands. Thus, Indigenous mining proponents find themselves doubly exiled in political discourse on the matter: from their transnational communities composed of Indigenous activists and international NGOs and from the position of recognized citizenry of Brazil. The dual nature of this exile is distinctive to contemporary rare earth politics, but the troubled relationship between Indigenous inhabitants and outsiders intent on remaking indigenous lands into a frontier to be conquered and exploited has an extensive history. Therefore in this case, another feature of the contestation over the rare earth frontier is the meaning, legitimacy, and scope of the legal protections provided by citizenship. Although these tensions are not unique to contemporary rare earth politics, they are nevertheless constitutive of them. As in Afghanistan, Greenland, and China, mining rare earth elements is the latest iteration of longer-term struggles to create and conquer a frontier, and to determine who belongs and who is trespassing.

\section{Amazonian Frontier: Four Centuries of Geology, Imperialism, and Nation Building}

The dynamics of the April 2014 encounter at CMA are rooted in several centuries of extralocal efforts to territorialize Cabeça do Cachorro regardless of existing local territorial orders. In effect, rare earth politics provide a contemporary iteration the struggle between extralocal interests and their multiple narratives that 
characterize the frontier as unproductive, empty, and problematic. Historically, as now, these frontier narratives clash with local desires to exercise resource-based economic agency. From imperial conquest to modernist nation-building projects, geological prospecting has been a key tool through which multiple powers have sought to discipline the northwest Amazonian frontier into a resource hinterland and a source of geopolitical power. The history of surveying and exploring the upper reaches of the Rio Negro is characterized by a rotating cast of aspiring hegemons with extractivist designs on the region.

Europeans first explored the upper reaches of the Rio Negro in the expedition of Pedro Teixeira in 1639 as part of a mandate by the Portuguese crown to consolidate control over the Amazon. Teixeira's expedition consisted of fortyfive canoes, seventy soldiers, twelve hundred archers, and conscripted Indigenous rowers (Miranda 2007). Along the way, Teixeira's expedition fought Dutch and English interests that had set up forts on the Amazon river and seized control over their Indigenous slave trade operations (Salvador 1627). The Spanish Jesuit Cristóbal de Acuña accompanied Teixeira in the hopes of finding Indians to catechize to expand the territorial scope of their missionary activities. Acuña also served as the expedition's chronicler, noting the abundance of precious stones visible along the rivers and on the surface of the soil. In his writings, he declaimed riches that appeared entirely disregarded by native inhabitants who apparently had no idea of their value (Acuña 1641).

Both religious and economic interests drove Portuguese territorial expansion on the upper reaches of the Rio Negro. In 1690, the Portuguese crown sent Carmelite missionaries to convert the Indians and solidify control over Amazonian frontier regions disputed with Spain. Their territorial strategy was typical of religious settlements of the time and crucial to state formation in frontier regions (Chernela 2014). Where they went, missionaries set up a convent, a farm, and a village, effectively creating the first imperial footholds in new frontiers. Established in 1695, São Gabriel was the first Portuguese settlement on the upper reaches of the Rio Negro. In order to sustain themselves, the Carmelites expropriated land and labor from the Indigenous inhabitants and began buying and selling Indigenous peoples with riverine slave traders (Hemming 1978).

This was a time of intense competition between multiple colonial powers intent on capturing the territorial and mineral bounty of the Amazon. Echoes of these early contests ring through contemporary debates over the Amazonian frontier, where it is routinely presented as a treasure nearly lost. For half a century, Spanish forts remained further to the north, where the Orinoco connects with the Rio Negro via the Casiquiare waterway. However, the 1750 Treaty of Madrid divided South America between Spanish and Portuguese powers; Portugal ceded part of the Río de La Plata and much of present day Argentina in 
exchange for control over a greater portion of the Amazon. To enforce the treaty, in 1761 the governor of the Captaincy of São José do Rio Negro at Barcelos ${ }^{22}$ organized several defensive patrols of the upper reaches of the Rio Negro. The patrols found that the drainage of the Orinoco into the Rio Negro provided a fluvial passage between the upper Amazon and the Caribbean Atlantic. Representatives of the Barcelos Captaincy promoted the possibility of developing a trade route to move timber, gold, and silver from this inland frontier to Europe. Two years later, frustrated by apparent imperial disinterest in the Captaincy's grand plans, they shifted the framing of their cause from trade to territorial threats. They made the case up the chain of command to the Office of the Secretary of State for Marine and Overseas Affairs of the Portuguese Imperium that improper defense of this region could jeopardize Portuguese control over the deep jungle (Bernardo e Mello 1763). The threat of losing control over the Amazon struck a fearful chord that resonates through to the present.

Alarmed at the prospect of losing the Amazonian frontier, the Office for Marine and Overseas Affairs responded by providing financing and manpower for a construction expedition. The Portuguese crown enlisted the services of German Military Engineer Phillip Sturm with instructions to attend to the solicitations of the Captain of Barcelos (Nabuco, Sampaio, and Rodriguez 1903). Sturm recommended the construction of two forts, one in present day São Gabriel da Cachoeira, and another upstream to mark the northern extreme of the Portuguese dominion near Cucuí, called the Forte de São José de Marabitanas. From these forts, Portuguese soldiers could expel Spanish settlements and defend against possible incursions via the Orinoco (Santos 2008). Despite its remoteness, Portuguese officials were convinced by the Barcelos contingent that Marabitanas would be the first part of the Amazonian frontier to be attacked by competing colonial powers (D'Almada 1785); therefore, militarizing the deep jungle was necessary. ${ }^{23}$

Despite Portuguese, and later Brazilian anxieties over incursions into its Amazonian claims, non-Iberian powers did not explore the Orinoco-Rio Negro-Amazon River network until World War II, when US rubber supplies were seriously jeopardized by the break in relations with Germany. At the time, US chemical companies had no idea how to produce synthetic rubber, and Japanese imperialist designs on Southeast Asia threatened supplies from Malaysia (Dean 1987). Meanwhile, trading routes from the Amazon River delta and the Atlantic were being "severely harassed by submarine attacks" (Engineers 1943, 1) that threatened US supplies essential wartime minerals and other primary commodities supplied by Brazil (Pecora et al. 1950; United States Geological Survey 1942-47). ${ }^{24}$ In response, US military and rubber interests looked to the Amazonian frontier. The US Army Corps of Engineers (1943) cooperated with the governments of Venezuela, Colombia, and Brazil to survey the 1,842 mile long Orinoco-Casiquiare-Negro Waterway with the 
purpose of identifying alternative shipping routes and "to further the understanding and development of that region by the sovereign governments." ${ }^{25}$

The survey team, composed entirely of US military personnel, conducted hydrographic and climatological surveying, aerial photography, and mapping of the route from the Caribbean to São Gabriel da Cachoeira. The final reports of this expedition were shared with regional governments, providing the first body of geological and geographical data to grant twentieth-century substance to the frontier narratives. On mineral wealth, the Army Corps of Engineers report noted that "the natural resources of the region are considerable, but, because of its comparative remoteness, not easy of development" (US Army Corps of Engineers 1943, 20).

This report provided baseline data for the first systematic Brazilian geological survey of the region, undertaken during the military dictatorship (1964-85). In the 1960s, a group of geologists participating in the preliminary border surveys observed a "chimney-like" hill protruding out of the northwestern Amazonian landscape outside of the city of São Gabriel da Cachoeira. This geological feature tends to be rich in ferrous and non-ferrous metals. It is a remnant of subterranean magma plumes that harden and remain as an eroded cylinder after the surrounding material has eroded away. As discussed in chapter 2, local nomads described the analogous formation at Bayan Obo as a "yurt."

In 1973, on the estimation that local mineral resources could sustain a regional industrialization project, the Twenty-First Engineering and Construction Company of the Brazilian Army relocated to São Gabriel da Cachoeira (Brasileiro 2006). This relocation occurred contemporaneously with the notorious military assault on Communist guerrillas in Araguaia, which had the effect of refracting the dictatorship's Amazon policies through the Cold War prism of dealing with communist threats (Portela and Neto 2002; Vecchi 2014). Anticommunist industrialization therefore defined the dictatorship's approach to Cabeça do Cachorro. As part of its relocation agenda, the Brazilian army trained a troop of Indigenous mercenaries in the upper reaches of the Rio Negro in case Communist guerrillas should occupy the region and interfere with plans to build an industrial mining hinterland to fuel Brazil's development (Ricci 2014). Although no major industry was ever built, it was in service of this right-wing nation-building agenda that DNPM conducted the RADAM ${ }^{26}$ geological survey of Morro dos Seis Lagos and São Gabriel da Cachoeira in 1975, during which the "chimney-like hill” was identified as the Morro dos Seis Lagos non-ferrous metals deposit (Corrêa, Costa, and Oliveira 1968), and is now described as the largest niobium and rare earth deposit in the world.

Geological survey was central to consolidating military dictatorship control over the Amazonian frontier, therefore it served as a cornerstone to national policy projects. The survey was organized across ten ministries and spearheaded 
by the Brazilian Air Force. It took place between 1970 and 1985, during which time the entire Brazilian territory was surveyed with aerial radar and mapped with over thirty-eight thousand logged flying hours (Souza and Cavedon 1984). The first phase (1970-75) covered 54 percent of the national territory, comprising primarily the Amazonian frontier and parts of neighboring countries (Momsen 1979). It later expanded to cover all of Brazil in the second and third phases: 1975-80 and 1980-85 (Archela and Archela 2008). This was a project of unprecedented scope. The radar technology allowed Brazilian surveyors to collect their first imagery unaffected by cloud cover (Momsen 1979). The Morro dos Seis Lagos carbonatite complex was recognized in 1975 after geologists published a report on the radioactive anomaly detected on the site (Hassano, Biondi, and Javaroni 1975). That year, CPRM conducted preliminary geophysical and geochemical explorations that consisted of drilling four samples between 110 and 255 meters in depth. The samples were only partially analyzed at the time. One veteran geologist interviewed reported that after they completed their initial reconnaissance of the radioactive anomaly at Morro dos Seis Lagos, US spy planes based in Panama conducted clandestine geological reconnaissance of the place. According to the story, Brazilian mapping of the Amazon rainforest apparently aroused the distrust of the United States with respect to Brazil's reportedly peaceful nuclear ambitions (Brazilian Nuclear History 1947-89; Cruz 2014; Souza and Cavedon 1984). It is not the truth or falsity of the account that is informative. Rather, it is the sense among Brazil's geologists, reflected in military policy, media, and popular culture that the country's Amazonian resources are coveted by the United States, which would like to establish greater control over the region. Brazilian exploration of the Amazon has been carried out under the perceived threat of US intervention.

To mitigate against the threat of foreign expropriation, a 1979 law placed matters of mineral exploration in frontier regions under the jurisdiction of the National Defense Council to significantly restrict access to the region's geological endowments. Without military authorization, mining activities "in areas indispensable to the security of national territory, especially in the frontier regions and with respect to activities related to the preservation and exploitation of natural resources of any type" could not proceed (PL 6634/1979). This law was enshrined in the Constitution of 1988 along with a moratorium on activities intending to occupy, fragment, or exploit Indigenous lands or their mineral wealth, unless specifically approved by Congress on a case-by-case basis (Cognresso Brasileiro 1988, Articles 231 and 232). By overlaying frontier security, mining prohibitions, and the integrity of indigenous territories, the constitution effectively froze the status quo of state control over the frontier. If the state did not have the immediate capacity to conquer this frontier, then neither could any other extractive interests be permitted, whether Luso-Brazilian, Indigenous, or foreign. 
The constitutional prohibitions on mining have had the effect of intensifying extralocal desires to exploit the region, especially among veteran architects of bygone state development failures who had built grand plans to capitalize on immense mineral wealth now "locked up" in Indigenous lands. Among these actors, there is a sense that the only thing holding back Brazil's development is a legal fluke resulting from the federal government's inability to stand up to foreign interests laundered through Indigenous movements. Because of this informal yet pervasive racial codification of citizenship, the sophistication with which Indigenous mining proponents defend rights over their lands deepens their symbolic exile from the Brazilian nation. Their visions of mining their own lands as a key to unlocking greater citizenship rights and recognition in Brazil have no place in a governance structure that only permits Indigenous agency to be exercised in traditionalist terms, and that views indigenous livelihoods as part of an ongoing frontier problem to be solved.

Beneath the racial codification of extractivism, the current disputes over rare earth mining in Cabeça do Cachorro are essentially struggles between industrial ${ }^{27}$ and artisanal ${ }^{28}$ mining. The former is generally understood as heralding the catastrophic penetration of capitalism into human communities, bringing war, death, and the death of nature. It is often counterpoised to the latter, or to that which industrial mining approaches seek to delegitimize: small-scale, family mining operations that complement other livelihood activities to provide a supplemental income to other subsistence activities drawn from the land and regional trade. Both forms of mining, of course, are motivated by profits. In the latter, mining is one family or community enterprise in which children, women, and men participate. It is extremely difficult to extract surplus value or tax revenue from such an arrangement, and so it is vilified. In Cabeça do Cachorro, industrial mining interests have relied on knowledge expropriated from local communities in order to access geological riches. Historically, the divulgation of geological secrets occurred informally, but also revealed the fragility of ties between Indigenous communities and outsiders of all kinds. Given the pitched battles for territorial control over the region, the handling of localized geological knowledge has been a matter of mortal consequence for Indigenous people and artisanal miners (Wright 2005). The struggles of the 1980s, in particular, shape contemporary rare earth politics in important ways. They are related in detail here. ${ }^{29}$

In late 1979, a group of Baniwa was heading over the border along the Serra dos Porcos to participate in Colombian gold mining when they discovered gold within their own lands. They informed people in their communities. News traveled up and down river, and Indigenous peoples from Colombia, Venezuela, and Guiana came to mine. In the first years, there were no whites, only Indigenous garimpeiros. By 1983, traders came to São Gabriel da Cachoeira to exchange goods 
for gold, and white garimpeiros joined the operations. Indigenous peoples set up a robust regulatory and permitting system to control the number of white garimpeiros allowed and collected a small tax on their findings, but it was never recognized by the government, military, or corporate actors.

This experience has informed their legal campaign with respect to rare earth mining. Several Indigenous interlocutors viewed rare earths as a "new gold." 30 Media commentators often used the same term, entrenching the idea. As a result, Indigenous peoples' approach to the question of rare earth mining on their land - whether for or against-is directly informed by a living memory of the violence and attempted seizure of their lands by an alliance among missionaries, mercenaries, mining companies and the military.

By 1984, the upper reaches of the Rio Negro was the site of one of the most intense searches for gold in the history of the Amazon. Private firms began sending agents and requesting licenses from the DNPM. Two of these firmsParanapanema and Goldmazon - conspired with the Governor of Amazonas to help state surveillance efforts in exchange for control over all mining activities in the region. The "New Tribes Mission," which had built basic infrastructure to support the evangelical activities headed by the American Sophie Müller, offered mining bosses the use of their remote landing strips and basic supplies.

Because the mining companies, the state, and foreign missionaries conducted themselves as though no regulatory systems governed extractivism in the region, despite the permitting and taxation system implemented by the indigenous people in the previous year, their foray into Cabeça do Cachorro was based on a world that did not exist. Where they encountered a reality that conflicted with their ideas of the frontier as empty, ungoverned, and unproductive, bloodshed resulted. In early 1985, representatives of the mining companies recruited Baniwa to carry heavy machinery, gasoline, and other supplies through thirty kilometers of jungle from the river to the primary mining site in the Serra dos Porcos. Upon arrival, representatives ordered the Indigenous to clear forest and to set up camp.

According to Wright's (2005) extensive ethnographic data gathered among the Baniwa, it was not clear to the Indigenous porters that the representatives were from large mining companies intending to expel garimpeiros or that the newcomers would attempt to expropriate Indigenous mines that had been operating for several years. When the Baniwa demanded payment for their porter services, mining personnel threatened them with obscene violence and ordered them to leave. In response, a group of sixty leaders from nearby villages prepared for war. In full battle regalia and armed with arrows and rifles, the Indigenous leaders surrounded the agents and offered them the options of leaving immediately, or staying and fighting. The corporate agents left immediately, leaving the operations to the Indigenous. 
The mining companies retaliated by conspiring with corrupt personnel working for FUNAI (National Indian Foundation) to hire mercenaries to go after the Indigenous leaders and intimidate them into signing agreements opening their lands to outside mining interests. Alarmed by this, representatives from fifty-four communities wrote a letter to the President of FUNAI in Brasília, Nelson Marabuto. ${ }^{31}$ They demanded the recognition of their rights to their lands; the removal of all outside mining interests; and the explicit proviso that, in the future, these communities would mine according to their own terms and with full discretion over technical assistance, production, and profits.

Indigenous peoples leveraged different forms of resistance-from armed to political—to regain control over their subterranean resources. Delegations traveled to Manaus and Brasília to petition higher levels of government to recognize their land claims and expel corporate mining agents. They held local meetings with mining representatives, community members, and government personnel. Many of these official efforts were fruitless in the short term as government and industry continued to "dribble the ball" 32 in terms of who was responsible for what in Indigenous territory. In late 1985, FUNAI president Álvaro Villas Boas sent a working group to research the mining and conflict situation and propose a series of measures to alleviate the tensions. The working group lacked any authority to implement its recommendations. One of the few concrete legislative changes that emerged was a territorial assertion on the part of the federal government stating definitively that the Serra dos Porcos was within Brazilian territory and that Colombians were prohibited from mining in Brazil. Colombians were not the problem, as far as the locals were concerned, so this did little to address the daily concerns of Indigenous peoples dealing with the ongoing intrusion of mining companies onto their land. Erasing Indigenous concerns, the federal government interpreted the conflict through the lens of geopolitical interests rather than a dispute among different groups of Brazilian citizens. Episodes of gruesome violence flared between Indigenous people and corporate miners, which survivors from both sides described as war.

From an Indigenous perspective, this represented the latest in centuries of white attempts to steal indigenous lands. From a state perspective, the conflict was an embarrassing illustration of government incapacity to rationalize and integrate the farthest reaches of its territory. From the military perspective, this conflict showed why integration schemes such as those that had failed in the 1960s and 1970 s were needed once again.

In fact, simultaneous to the conflict, the Brazilian military had been developing a program — the Northern Trench Project (Projeto Calha Norte; PCN) - to militarize the Amazonian frontier following the failures of the massive integration projects of the 1960s and 1970s. Under the twin banners of development and 
sovereignty, ${ }^{33}$ it was conceived in order to provide a justification and operating budget for maintaining a military presence in Cabeça do Cachorro despite growing evidence of military abuses of Indigenous peoples (Instituto Socioambiental 2001; Ricardo and Ricardo 1990). ${ }^{34}$ This was a frontier-taming proposal par excellence. Submitted to President José Sarney in June 1985, it proposed to better integrate the region into Brazil, develop the local economy, and assimilate Indigenous people into the Brazilian population, which—it was hoped-would eventually eliminate the need for any specially demarcated indigenous lands.

The proposal sat unaddressed for months. As with the preindependence proposal from the Captaincy of Barcelos to the Portuguese crown, it took the invocation of an immediate threat to the region to receive a response from on high. On November 6, 1985, the international press exploded with news of a siege by the Colombian Armed Movement M-19 on the Colombian Supreme Court in Bogotá. Although the attack had taken place roughly a thousand kilometers away from São Gabriel da Cachoeira, and although the M-19 movement claimed less than two thousand members who were overwhelmingly based in urban areas in Colombia, military personnel capitalized on popular fears of jungle guerrillas in Brazil. A propaganda campaign cynically mixed accounts of Indigenous attacks on corporate mining personnel and broader cultural anxieties about attacks on Brazilian territory by circulating rumors that guerillas were building up an arsenal on the border in order to invade and capture Brazilian gold (Hayes 1986). The propaganda worked. President Sarney approved the project in December 1985. ${ }^{35}$ In subsequent cooperation with representatives from the United States' Drug Enforcement Administration, the Brazilian military determined that the upper reaches of the Rio Negro would serve as a "test case" for their Amazonian occupation, surveillance, and assimilation program. ${ }^{36}$

Although the guerilla attacks on Brazilian territory never materialized in 1985, the specter of FARC (Revolutionary Armed Forces of Colombia) incursions has been periodically invoked to justify the military presence in Cabeça do Cachorro. Guerilla leaders have been clear that they do not wish to engage in armed conflict with the Brazilian military, ${ }^{37}$ but neither does the Brazilian Ministry of Defense wish to appear that it is lagging on the offensive against FARC, lest the US military decide that its needs to increase its presence in the region (Filho 2006). ${ }^{38}$ This dramatically underscores the conventional geopolitical needs driving ongoing state attempts to industrialize the region. Tearing up the impenetrable green and rationalizing the space with large scale rare earth mining operations would powerfully demonstrate not only Brazilian control over the region, but also advance a specific, anti-indigenous notion of Brazilianness.

Perhaps this helps explain why nothing in the Constitution or related laws expressly prohibited DNPM from issuing mining concessions in Indigenous lands 
so long as applicants followed the proper permitting procedures. Furthermore, the moratorium did not nullify existing mining concessions in the region, but rather placed them in a state of suspension until such time that the mining code could be revised to permit mining on Indigenous lands. Such a proposal came in 1996 in the form of Senator Romero Jucá's PL 1610. Under discussion for over two decades, this law would overturn the constitutional mining moratorium in Indigenous lands and allow prospecting firms the same rights of exploration as permitted on nonprotected lands, without providing a process for Indigenous inhabitants to contest or modify mining concessions on their territories. Banking on the success of PL 1610, the number of mining concessions acquired in São Gabriel da Cachoeira increased from thirty-six before the ratification of the Constitution to 401 just after the turn of the millennium (Ricardo 2013).

Large-scale industrial mining interests tend to present themselves to state counterparts as killing two birds with one stone. Not only would Amazonian mining activities contribute to national development, the requisite logistical support infrastructure would also help manage the multifarious threats to the Amazonian frontier. Whether these threats are believed to be military, guerrilla, or environmental, their periodic invocation of a vulnerable frontier in political and popular discourse effectively generated mass consent for the largest defense procurement deal in the history of Brazil.

At just over US\$1.4 billion, the Amazonian Surveillance System (Sistema de Vigilância dos Amazonas; SIVAM) is the world's largest environmental monitoring network. It was conceived during the presidency of Fernando Henrique Cardoso (1995-2003) and came online in 2002. One of its principle objectives is to monitor and collect data about natural resources in the Amazon in order to further the modernization task of completing an inventory of national riches (Nascimento and Sá 2008). Using a combination of ground and aerial radar, this "system of systems" was built to monitor drug trafficking; illegal mining, ranching and deforestation; agrarian conflicts; and invasions on Indigenous lands. ${ }^{39}$

Implementing SIVAM required a twenty-first century remilitarization of the Amazonian frontier in the name of surveillance, which reached beyond the developmentalist ends of the PCN. In 2004, the Brazilian army relocated the First Strategic Brigade of Niterói in Rio de Janeiro to São Gabriel da Cachoeira. This was presented as part of a new orientation of the Brazilian military in response to poorly defined "new" international pressures (Filho and Vaz 1997; Messias da Costa 2013). But in fact the remilitarization of Cabeça do Cachorro does not seem to reflect any profoundly new thinking about the Amazon in general or the upper reaches of the Rio Negro in particular. Perhaps it is most accurate to describe the military as reviving its foundational strategies to address what has long been 
perceived to be the greatest national vulnerability. The push to mine rare earths in the region is in many ways the latest iteration of the struggle to conquer the northwestern Amazonian frontier.

Clearly, the drive to exploit the region long precedes the identification of rare earth elements. Furthermore, the very possibility of mining them in Cabeça do Cachorro was not seriously considered until decades after they were discovered. The histories of São Gabriel da Cachoeira from the 1600s to the late twentieth century show successive attempts on the part of imperial and state actors to rationalize the region through the production of cartographic and geological knowledge. Where that knowledge was contested, violent geopolitical struggles resulted. These bodies of knowledge about the Amazonian frontier have been generated and deployed by Imperial Portuguese as well as military actors from the US and Brazil in the hopes of capitalizing on the region's resources and assuage broader territorial and geopolitical insecurities. Indigenous claims to the land and resources have only been recognized since the late twentieth century. These too are under threat.

In 1985, ten years after the RADAM-BRASIL survey of São Gabriel da Cachoeira, state geologists calculated that Morro dos Seis Lagos contained a reserve of 81 billion tons of niobium at 2.898 percent concentration, which was fourteen times the known global reserves at the time (Justo and Souza 1986). The deposit was also found to possess remarkably high concentrations of rare earth elements as well as vanadium, beryllium and zirconium (Radambrasil 1976). In this period preceding the proliferation of rare earth-based information and military technologies, these findings did not stimulate much practical interest (Rossini 2012). After the successful demarcation of Indigenous lands in 1987 and biological reserves in $1990,{ }^{40}$ all further state geological research was halted. Excitement over the region's rare earth and other technology metals is a phenomenon that emerged after the 2010 crisis awoke Brazilian researchers to the importance of rare earth elements.

\section{Contested Hinterland: Extractivism, Geopolitics, and Militarism, 2010-2014}

The question of geological mapping of Brazil is far from being resolved. What is clear, however, is that Brazilian geology is still unknown compared to other mining nations. This represents an excellent opportunity for businesses especially focused on exploration, in search of potential activities in frontier regions such as the Amazon ... 
The RADAM-BRASIL samples were taken out of storage for further analysis in the immediate aftermath of the rare earth supply crisis. In December 2010, a joint research group between the Federal University of Rio Grande do Sul and the National Council of Research on the Mineralogy and Geochemistry of Mineral Deposits reopened investigations into the Morro dos Seis Lagos deposits. This initiative was overseen by CPRM doctoral fellow Mateus Marcili Santos Silva, who had participated in large-scale hydrographic mapping initiatives and was therefore able to gain access to samples through his colleagues at CPRM. But the project was dealt an unexpected setback when Silva died in a car accident in July 2011 ("Obituário" 2011). Analysis did not resume until nearly a year later.

Subsequent analyses carried out by members of this research group using the samples that were made available to the late Mr. Silva found concentrations of heavy rare earth elements between 5 and 10 percent (Giovannini 2013), which is exceptional compared to other sites that successfully garnered investment based on concentrations of between 0.9 and 2.2 percent. ${ }^{41}$ In addition to the resources at Morro dos Seis Lagos, there is an abundance of rare earth elements, coltan, vanadium, and other elements now considered "strategic" or "critical" present in alluvial deposits and clays on Indigenous lands elsewhere in Cabeça do Cachorro. This new information revived Senator Romero Jucás infamous PL 1610. In June 2013, President Dilma Rousseff sent a mandate to Congress to formulate a new mining code that would be "favorable to business and to productive investments that would strengthen a new cycle of development in our country, but all with gains for society, for workers, and for the environment" (quoted in Bustamente et al. 2013).

This became PL 5807 of 2013, and was anxiously awaited by the mining sector, which had hoped that the charged geopolitical climate surrounding rare earth elements would facilitate lifting the moratorium against mining on Indigenous lands (Bustamente et al. 2013). Corporate mining interests lobbied Congress with claims that the nation was at a critical point to determine its future development and standing in the global economy. Industry was quick to buy influence among politicians. For example, mining companies contributed at least $\mathrm{R} \$ 1.8$ million to the reelection campaign of PL 5807's sponsor, Senator Leonardo Quintão, which comprised 37 percent of his entire 2013 campaign budget (Souza 2014). Efforts to force through the bill on the pretext of national urgency failed, however, as the price of rare earth elements stabilized and allegations of bribery and corruption surfaced (Instituto Socioambiental 2013). As of this writing, the bill has yet to be voted on. A substantially similar bill, PL 5263, was introduced in June of 2016 to liberalize mining in Indigenous lands, but does not govern radioactive materials. Therefore it is unclear what this might mean for rare earth elements, given their common association. 
Since 2010, some DNPM and CPRM geologists have taken a proactive stance on exploiting the rare earth riches of Cabeça do Cachorro which, despite extensive survey data, is problematized by state geologists as the least known geological region of Brazil (Santos 2003). By maintaining that Indigenous and international NGO efforts to keep the region undeveloped have undermined the scientific and economic potential of Brazil, geologists have found a welcoming audience among the Ministry of Defense. The Ministry of Defense takes care to include the most outspoken among state and Indigenous mining proponents in high-profile military events across the country, such as the gathering described in the first section of this chapter. Reopening Indigenous lands to large-scale mining operations would enable the military to extend its agenda of industrialization-driven consolidation of the northwest Amazonian frontier.

After the 2010 rare earth crisis, the budget for the PCN increased precipitously, from R $\$ 250$ million per year to $\mathrm{R} \$ 770$ million in $2013 .{ }^{42} \mathrm{PCN}$ Director Brigadier Dantas attributes this to "the growing confidence Senators have in our initiative" as well as "growing awareness of the need to protect São Gabriel da Cachoeira's resources from Colombian and Venezuelan garimpeiros by integrating the region into Brazil." 43 Here again, the extractivist threat was internationalized at the expense of Indigenous claims to frontier resources.

The post-2010 circulation of geological knowledge reinvigorated efforts to intensify Brazilian state control over a frontier region that had been, in practice, more integrated with the mineral, cocaine, rubber, and contraband markets in Colombia. In 2014, rumors again circulated about alleged plots against two separate Brazilian army bases. As with most other rumored plots in the past decades, these attacks never materialized. ${ }^{44}$ Invoking FARC to amplify the perceived threat of foreign garimpeiros and to justify expanded military presence in the Amazon serves two purposes. The first is to engender broad public support for the ongoing militarization of the Amazon, and the second is to ward off potential encroachments by the US military.

Brazilian military officials express discomfort with the enduring US military presence in Colombia (Marques 2007) since this represents a major global occupying power fortifying its military facilities near Brazil's porous Amazonian border. This has compelled the military to formulate offensives in the region in order to enclose possible spaces in which the US military might decide to intervene. In one such case, the CMA reframed the fluid transborder economies as a violation of Brazil's sovereignty and undertook joint training exercises with the air forces of Colombia, Peru, and Venezuela. To simulate illicit trafficking, they deployed small airplanes to fly at low altitude along the border of Brazil and participating neighbor states. They practiced radar detection and mid-air interceptions (Marques 2007). The practical motives of these exercises are unclear, 
given that the majority of the commodities, legal or otherwise, are moved in small quantities, boat by boat, in an "ant-like" (formigando) fashion up and down river. Both military and federal police interlocutors in São Gabriel da Cachoeira professed a fundamental incapacity to monitor these small-scale riverine movements on a regular basis. ${ }^{45}$

There is no place for Indigenous economic agency in the national imaginary: at worst, Indigenous activists are viewed as traitors, and at best, they are seen by the state as incapable of defending themselves against foreign incursions. The historical vulnerability of Indigenous populations to imperial and state violence has been reframed as a fundamental national vulnerability against an imagined external threat, and against which the Indigenous cannot be trusted to defend the country.

What is new in this contemporary era of neo-extractivism is the intensity with which the need to defend the Amazon has caught hold of the Brazilian popular imagination. Once thought to be a punishment, posts in the Amazon are now among the most sought after among military officers (Marques 2007). If anything has changed about the older feelings toward the Amazon, it is a sense of morally and technologically empowered purpose emerging out of several years of broader national political economic ascendancy. But the contemporary attitude of the military and the federal police toward Indigenous inhabitants has changed little from the colonial era. Indigenous people are still discursively framed as the counterpoint of civilized Brazilians, lacking the initiative to work, improve themselves, or even practice good hygiene (Castro 2003; Marques 2007). ${ }^{46}$ In these discourses, Indigenous people do not count as a living presence on the Amazonian frontier, as illustrated by the military strategy to "vivify" the frontier with military colonies:

Thanks to the PCN there has been an accentuated vivification on the frontier zone, based in the presence and deployments of the Special Frontier Platoons. If it weren't for the PCN, what would we have in this Amazonian vastness? . . . For the strategists, the Special Frontier Platoons are today little points of "national civilization" holding our frontier together, with the hope that in the future they will transform themselves into human agglomerations, small towns, small cities, municipalities. (Nascimento and Sá 2008, 41)

However, these antiquated attitudes must now reckon with the fact that Indigenous polities are well organized on the regional, national, and international scale. Chastened by the well-publicized disgraces of the colonial and mid-century extermination practices in the name of greater geopolitical control over the Amazon (Ricardo et al. 2014), the Brazilian military has been compelled to change its approach to the frontier. The necropolitics of the past, in which state-directed 
campaigns of mass death aimed to rid the frontier of those with competing territorial claims in the name of development, have given way to the " 100 percent transparent" 47 biopolitics (Foucault 2007) of the present. This is evident in the language of assimilation and vivification used to describe state and military proposals to develop the frontier.

Beneath this changing approach is an underlying continuity of objectives. For planners in the federal state and military, large-scale industrial mining remains the ideal means for rationalizing Cabeça do Cachorro. Rendering these continuities palatable to local citizens obliged the military to undertake an extensive propaganda campaign in order to vilify small-scale mining operations. This campaign precedes the excitement over rare earths, but also sets the terms in which the debate unfolded over who is entitled to these strategically valued resources. Switching its politics from necro to bio further obliged the military to reconfigure public perceptions of difference between civilized Brazilians and Indigenous "others." With respect to mining, this involved recodifying legitimate and illegitimate extractive activity in terms of enlightened patriots and environmental criminals traitorous to Brazil. Corporate mining interests were codified as "us": legitimate and law-abiding, while garimpeiros were codified as "them": outlaw others bent on destroying Brazil's natural wealth.

One key program through which this project unfolded was in fact SIVAM, the massive satellite surveillance program. The SIVAM Social Communications Advisory Team developed the mascot of a young, light-skinned Indigenous boy wearing athletic shorts and a Yanomami-esque haircut named Sivamzinho (Little SIVAM). The promotional materials provided the following explanation: "This nice little Indian is Sivamzinho, mascot of the SIVAM project. He's the number one friend of the children of the Amazon" (SIVAM 2008 quoted in Guzmán 2013, 111-12). Over one million pieces of pedagogical materials, such as pencils, rulers, posters, calendars, and notebooks, were distributed to schools in the Amazon, particularly those sites targeted for the construction of SIVAM infrastructure. Another five hundred thousand notebooks distributed in Amazonian schools showed Sivamzinho raising the Brazilian flag and singing the national anthem.

This is another case, like that examined in Inner Mongolia, wherein the conventional and critical geopolitics intersect in the formation of desirable frontier subjects, to "generate a legion of Sivamzinhos" by connecting with Indigenous children's "love of the land" and "spirit of adventure" across the Amazonian frontier (SIVAM 2008 quoted in Guzmán 2013, 111-12). The military developed this explicitly raced and gendered social mobilization project to generate proper popular feelings toward the world's largest environmental surveillance and law enforcement regime. The geopolitical stakes are clear: if the Indigenous presence 
must be accommodated, then it is imperative to convert Indigenous people into assimilated citizens on whom the Brazilian state could depend to accept the project of rationalizing the Amazonian frontier into a national hinterland. This would occur through efforts to eliminate small-scale resource exploitation in the interest of eventual industrialization. Toward this end, a series of comics depicted Sivamzinho reporting wrongdoers such as garimpeiros and Anglo-European poachers - note the configuration of otherness - to the federal police, and then speaking directly to the reader about his love of the Amazon and his resolve to fight against those who destroy it. There are no comics in which Sivamzinho vilifies mining companies, military bases, or missionaries.

This may not seem unusual for a military-backed propaganda campaign. Viewed in historical context, it is one of many bold attempts to erase a history of violence visited on Indigenous peoples by states, missionaries, militaries, and mining companies. The subject of mining is especially fraught, where corporate mining is positioned with national development while small-scale mining, as in Inner Mongolia, Afghanistan, and elsewhere, is vilified and presented as anathema to the nation. The power of these discourses is visible in the difficulty with which indigenous interviewees expressed themselves on the topic of mining. They found it difficult to even talk about mining without also navigating the anguish generated by memories of violence in the 1980s. Yet the public discourse overwhelmingly attributes the horrors of the period to small-scale production rather than state-backed corporate mining. Therefore those arguing for indigenous controlled rare earth mining must also address the connotations of treason and illegality with which artisanal mining has been imbued. In the China case, local informal miners and sympathetic officials could use the same language as the national government to assert the legitimacy of their operations in providing raw materials to downstream industries. In the Brazil case, there was neither the political concept nor the immediate industrial need to help indigenous mining proponents advance their claims. These ambiguities weighed heavily on the psyches of Indigenous mining proponents interviewed in São Gabriel da Cachoeira, who were doubly exiled from transnational environmental conservation communities, on the one hand, and from the Brazilian national community, on the other, by virtue of their desire to mine their own lands.

The conditions of impossibility in which Indigenous mining proponents find themselves calls into question the depth of the critiques of the "noble savage" in academic and other discourses. If we are serious about deconstructing fixed notions that equate Indigenous people with partial and problematic notions of wilderness stewardship, then we need to be prepared to recognize critical instances of agency as exercised by Indigenous people-even if such actions upset established notions of the relationship between Indigenous people and mining. 
However, as shown by the multiple attempts to coopt indigenous claims to mining-based agency, mining on indigenous lands is a proposition fraught with hazards. These hazards are entirely distinct from the obvious market and logistical constraints to mining rare earths in this region. Diverse actors, each of whom sees these elements as the key to unlocking diverse possible futures, strategically value rare earth elements in different ways. Indigenous mining proponents saw them as the means through which to finally capture legitimate recognition from the state. The state saw them as a means to fulfill three territorial ambitions at once: territorialize the remotest Amazon, promote national development, and capture international recognition. These aims to bring about Brazil's future through rare earth development were racially coded. Federal government and military interviewees did not equate an increase in Indigenous power with the consolidation of state power on the frontier. Quite to the contrary: any advance in indigenous power-especially autonomous economic power-was discussed as a threat to the security of the territorial state. Rare earths, discursively cast as "strategic elements" and "bearers of the future," highlighted this antagonism. For whom would rare earths bring the future? And what sort of future would that be?

\section{Conclusion}

I repeat, Madam President, rare earths are a matter of national sovereignty, whether to provide advances in knowledge, whether for the multiplicity of its uses, including in the defense and oil industry. Therefore, we need a strategic policy to foster its production and prioritize entrepreneurial boldness to process deposits into products that are capable of nourishing the most advanced industries existing in the world today. This is a crucial issue for the future of our country.

—Senator Luiz Henrique da Silveira (2013)

This chapter argued that the paradoxes currently characterizing rare earth exploration in Brazil cannot be explained by a simple economic calculus. Longstanding contests over sovereignty and citizenship rights are at the heart of the impetus to exploit rare earth elements in the challenging context of the northwestern Amazon-despite the ongoing production of more sustainably produced rare earth oxides in the heartland. This shows that despite the discourses of neoextractivism in Brazil in the context of rising BRICS hegemony, strategic resource concerns continue to be powerfully shaped by (post)colonial desires to control the Amazonian frontier. Military-industrial mining interests in Brazil saw themselves as fighting the battle for rare earths on three different scales: competing with China 
internationally, defending a certain vision of sovereignty over the Amazonian frontier regionally, and suppressing indigenous claims to economic sovereignty locally.

Although the actual scale of rare earth extraction at the time of my research was miniscule-ant-like, in local parlance-the stakes were nevertheless high. In this place where there is a decades-old moratorium on commercial mining activity, a multitude of national, local, and transnational actors have undertaken regulatory offensives in order to legitimate their particular vision of rare earth exploitation. At stake in these multiple regulatory offensives to change existing Indigenous and environmental protection laws is control over defining the future of the Amazonian frontier. These definitions determine whether rare earth extraction translates into greater geopolitical control as envisioned by the military, or greater citizenship rights and fuller participation in the Brazilian economy as envisioned by garimpeiros and Indigenous activists. The feasibility of rare earth exploitation in such a place is secondary to the ways in which multiple actors imagine it might support their varied territorial agendas.

The dreams of rare earth elements or, more precisely, the dreams of power and sovereignty imparted by control over their extraction, are entangled with ongoing struggles over the meaning of the Amazonian frontier and entitlements to geological patrimony. Generals, investors, geologists, environmentalists, and Indigenous activists all conceive of rare earth elements in Cabeça do Cachorro as essential to their respective visions of the future. Amid these competing visions, there is also the recognition that regardless of how rare earth elements are extracted, whoever captures authority over their extraction stands to gain tremendously. Given this, it is possible to see how research on the high geological incidence of rare earth elements in the region intensified competing territorial contests in the upper reaches of the Rio Negro. This chapter has presented some of the lived and material consequences of such fantastic dreams, where the rare earth frontier reaches to the far northwestern Brazilian Amazon. The political power of fears and fantasies is especially salient in the next chapter, where some are attempting to extend the rare earth frontier beyond our Earthly confines. 